\title{
PROSES DAUR ULANG REFRIGERAN YANG TERCEMAR SEBAGAI UPAYA PELESTARIAN LINGKUNGAN DAN PENGHEMATAN
}

\author{
Kemas. Ridhuan \\ Jurusan Teknik Mesin Universitas Muhammadiyah Metro \\ J1. Ki Hjar Dewantara No. 116 Kota Metro \\ kmsridhuan@yahoo.co.id
}

\begin{abstract}
Abstrak
Zat-zat sintetik buatan manusia seperti refrigeran CFC (chloro fluoro carbon) seperti R 12 dan R 22 yang banyak digunakan terutama pada alat-alat pendingin dan tergolong sangat merusak lapisan ozon. Dalam aplikasi lapangan banyak terjadi pelepasan atau pembuangan refrigeran (freon) seperti pada saat servis karena refrigeran tersebut telah bercampur dengan pelumas atau air dan ini tidak baik lagi digunakan karena akan merusak alat. Cara yang aman dan efisensi untuk mengatasi hal tersebut adalah dengan cara mendaur ulang refrigeran yang tercemar tersebut. Tujuan dari penelitian ini yaitu untuk mengetahui proses daur ulang refrigerant dan efisiensi pemisahan refrigerant yang terjadi. Metode penelitian yang dilakukan yaitu proses daur ulang pada alat/mesin 3-R ( recovery, recycle, recharging). Jenis refrigeran yang akan didaur ulang adalag CFC R-12. Pertama proses tersebut mengeluarkan refrigeran dari sistem (alat pendingin) dengan cara vacum lalu menyimpannya, kemudian refrigeran tersebut didaur ulang pada mesin recovery dalam bentuk uap atau cairan masuk melalui filter driel. Uap refrigeran dan pelumas cair akan terpisah berdasarkan prinsip garavitasi. Refrigeran akan dikondensasikan di kondensor kemudian masuk ke tangki penampungan. Selanjutnya refrigeran diproses pada mesin recharging untuk dimasukkan kembali ke sistem (alat pendingin). Hasul penelitian yang didapat menunjukkan hubungan antara tekanan dan temperature. Rata-rata ukuran refrigeran yang didaur ulang; massa 24 gram, tekanan 15 psi dan temperatur $12{ }^{\circ} \mathrm{C}$. Efisiensi massa refrigeran yang diperoleh setelah daur ulang $84,83 \%$ dan massa pelumas $11,84 \%$ serta massa kehilangan akibat menempel atau tersaring 3,33 \%. Ini menunjukan bahwa proses daur ulang sangat efektif, selain untuk menanggulangi perusak lapisan ozon, juga dapat menghemat pengeluaran untuk pembelian refrigeran serta dapat mempertahankan keawetan sistem (alat pendingin) seperti kompresor dan evaporatornya.
\end{abstract}

Kata Kunci : Refrigeran, Ramah lingkungan, Daur ulang

\section{PENDAHULUAN}

Masalah lingkungan global adalah persoalan kerusakan lingkungan hidup yang dampaknya dirasakan seluruh wilayah di bumi (global). Masalah lingkungan global yaitu berupa perusakan lapisan ozon dan gejala pemanasan global.

Lapisan ozon berfungsi sangat penting bagi kehidupan di bumi. Lapisan ozon bertindak sebagai filter untuk mencegah masuknya radiasi ultra violet matahari (UVB) yang berbahaya, supaya tidak sampai ke permukaan bumi. Perusakan lapisan ozon disebabkan karena banyaknya zat-zat sintetik buatan manusia diantaranya adalah refrigeran CFC. (SNI, 2000)

Refrigeran CFC (chloro fluoro carbon), seperti R 12 dan R 22 adalah salah satu jenis refrigeran sintetik yang banyak dipakai di Indonesia dan tergolong refrigeran yang sangat merusak ozon dilapisan stratosfir. Perusak ozon merupakan hal yang serius, karena berakibat meningkatnya jumlah sinar ultra violet (UV) yang kita terima. Hal ini akan meningkatkan kasus penyakit kanker kulit dan katarak mata, mempengaruhi ikan dan biota laut serta penurunan imunitas (daya tahan) tubuh (GTP, 2006)

Refrigeran atau Freon adalah suatu fluida kerja yang digunakan di dalam mesin pendingin atau sistem refrigerasi yang berfungsi untuk menyerap panas dari benda atau udara yang didinginkan lalu membawanya, kemudian membuangnya ke udara sekeliling diluar benda.

Refrigeran CFC akan merusak ozon bila dilepaskan ke udara, hal ini biasa terjadi pada waktu perbaikan alat pendingin atau pada saat pengisian ulang refrigeran maupun terjadi kebocoran pada system (alat). Pada saat perbaikan ataupun pengisian ulang pada 
alat pendingin di bengkel atau tempat servis biasanya refrigeran (freon) yang masih tersisa di dalam tabung langsung di buang ke udara luar atau di alam bebas karena refrigeran (freon) tersebut telah bercampur dengan oli pelumas kompresor atau air ataupun zat yang tidak menguap di dalam tabung (Mulyanef, 2007).

Oleh karena itu refrigerant yang tercemar tersebut harus didaur ulang selain untuk menjaga lingkungan juga menjaga kerusakan alat pendingin serta menghemat pemakaian refrigerant.

\section{LANDASAN TEORI}

\section{a. Mesin Refrigeran}

Refrigerasi adalah proses penyerapan panas sehingga temperatur suatu produk atau zat menjadi lebih rendah dari temperatur lingkungannya, jadi mesin atau system refigerasi adalah mesin atau sistem yang dapat menimbulkan efek referigersi, dimana Refrigeran adalah fluida kerja yang digunakan dalam mesin atau system refrigersi untuk menyerap panas.

Teknik pengkondisian udara tidak hanya berfungsi sebagai pendingin tetapi lebih dari itu definisi penkondisisan udara nyaman adalah proses perlakuan terhadap udara untuk mengatur suhu, kelembaban, kebersihan, dan pendistribusiannya secara serentak guna mencapai kondisi nyaman yang dibutuhkan oleh penghuni yang ada di dalamnya.

Jenis mesin refrigerasi yang apling banyak digunakan adalah Mesin Refrigerasi Kompresi Uap. Susunan komponen mesin refrigerasi ini secara skematik diperhatikan pada gambar 2.1. Komponen utama dari mesin refrigerasi ini adalah : Kompresor, Evaporator, Kondensor, Pilter Driel, Pipa Kapiler (Stoecker, 1989).

\section{b. Mesin 3R}

Mesin 3R adalah suatu mesin yang berfungsi sebagai recovery, recycling, dan recharging. Mesin ini bekerja mengeluarkan serta menangkap refrigeran, kemudian mendaur ulang refrigeran yang ditangkap dengan cara memisahkannya dari pelumas dan menyaring kotoran padat yang terdapat dalam refrigerant tersebut (GTP, 2006).

Prinsip kerjanya mesin recovery, recycle dan recharging dibagi menurut sistem recycle-nya, yaitu laluan tunggal dan multi laluan. Laluan tunggal proses pemurnian refrigeran dilakukan hanya satu kali sirkulasi saja. Sedangkan multi laluan sirkulasi berulang-ulang. Banyaknya receiver dryer dan pipa-pipa kapiler yang digunakan pada sistem mesin 3R laluan tunggal lebih sedikit dibandingkan mesin 3R multi laluan (Mulyanef, 2007).

Proses daur ulang dilakukan pada alat yang disebut dengan 3-R (Recoveri, Recycle, Recharging.). Yaitu suatu proses yang dilakukan untuk mengeluarkan refrigeran yang tercemar dari system dan menyimpannya pada tempat diluar system. Lalu refrigeran tersebut didaur ulang yaitu suatu proses pemisahan antara refrigeran dengan oli, air dan zat lainnya. kemudian mengisikannya kembali pada tempat tabung inti. Proses daur ulang harus dilakukan dengan teliti, seksama dan hati-hati serta sesuai dengan prosedur yaitu dengan menggunakan alat keselatama kerja (SNI, 2000).

\section{c. Proses Recovery}

Proses recovery merupakan suatu proses dimana refrigeran dikeluarkan dari sistem pendingin, sehingga refrigeran tersebut tidak terlepas ke atmosfir atau proses mendapatkan kembali refrigeran dari sistim AC (SNI, 2000).

Proses ini dapat dilakukan dengan 2 cara yaitu :

1). Pengeluaran muatan refrigeran secara alami yaitu pengeluaran refrigerandari sistem (alat pendingin) ke tabung penampung berlangsung akibat adanya perbedaan tekanan

2). Pengeluaran muatan refrigeran dengan menggunakan kompresor sistem untuk mendapatkan perbedaan tekanan yang lebih besar antara sistem dengan tabung penampung. 


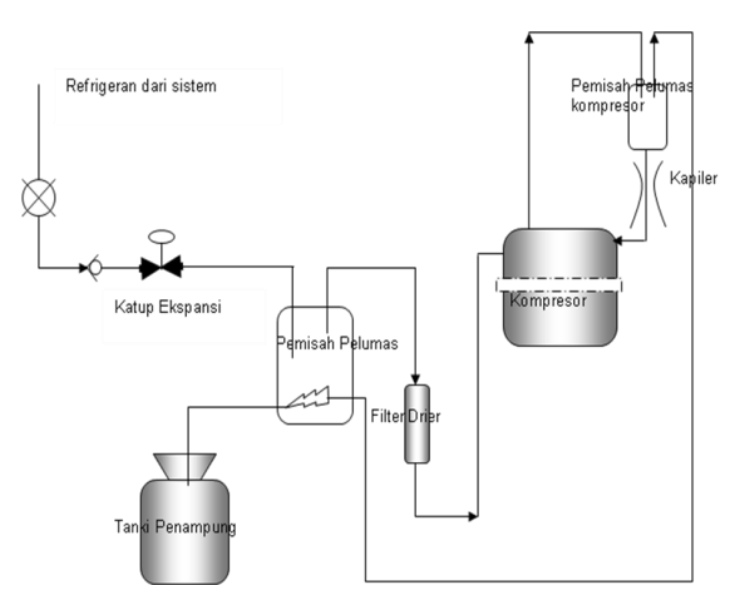

Gambar 1. Metoda Recovery Aktif

\section{d. Proses Recycle (Daur Ulang)}

Recycle yaitu proses pemurnian atau pencucian refrigeran dari proses sirkulasi di dalam mesin 3R. Pemurnian refrigeran dari partikel-partikel padat dan pelumas yang bercampur selama mesin pendingin bekerja, bertujuan supaya refrigeran tersebut dapat digunakan kembali (Mulyanef, 2007).

Refrigeran yang tercemar dengan air dan pelumas jika digunakan akan merusak sistem (alat pendingin) maka perlu didaur ulang.

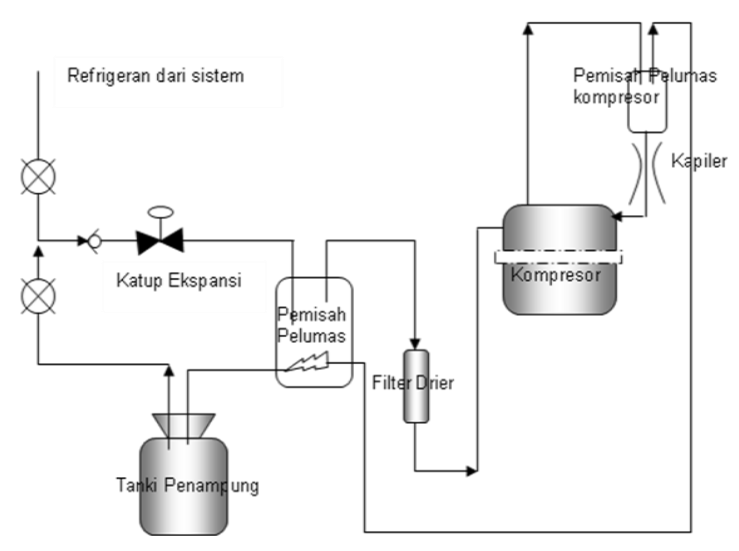

Gambar 2. Proses Recycling

Proses recycle ini terjadi pada refrigeran dalam bentuk uap atau cairan masuk ke mesin recycle melalui filter drier. Untuk menyakinkan tidak ada cairan refrigeran yang masuk ke kompresor, maka pemisah pelumas dipanaskan oleh refrigeran yang keluar dari kompresor. Uap refrigeran dan pelumas cair akan terpisah berdasarkan prinsip gravitasi (Mulyanef, 2007).

\section{e. Proses Recharging}

Proses recharging adalah proses pemasukan kembali refrigeran yang telah didaur ulang ke sistem (alat pendingin) sehingga dapat digunakan kembali dan dapat dicampurkan dengan refrigeran yang baru.

Data hasil pengujian yang diperoleh kemudian dihitung dengan persamaan sebagai berikut :

1) Persentase hasil refrigerant $(\mathrm{Re})$

$$
\operatorname{Re}=\frac{\text { Wri }}{\text { Wro }} \times 100 \%
$$

Keterangan :

Wri $=$ Massa refrigeran setelah daur ulang (gr)

Wro $=$ Massa refrigeran sebelum daur ulang (gr)

2) Persentase hasil pelumas (Pe)

$$
\mathrm{Pe}=\frac{\text { Wpi }}{\text { Wro }} \times 100 \%
$$

Keterangan :

$\mathrm{Pe}=$ Persentase pelumas yang diperoleh $(\%)$

$\mathrm{Wpi}=$ Massa pelumas setelah daur ulang $(\mathrm{kg})$

3) Jumlah massa kehilangan (Wki)

$$
\text { Wki }=\text { Wro - Wri - Wpi }
$$

4) Persentase massa kehilangan $(\mathrm{Ke})$

$$
\mathrm{Ke}=\frac{\text { Wki }}{\text { Wro }} \times 100 \%
$$

\section{METODE PENELITIAN}

Penelitian ini dilakukan di Laboratorium teknik mesin Universitas Muhammadiyah Metro. Sampel yang diambil adalah Refrigeran (Freon) CFC seri metana 12, Freon yang di daur ulang adalah sisa alat pendingin lemari es rumah tangga. Dengan mengambil 5 buah sampel froen yang akan di daur ulang. 


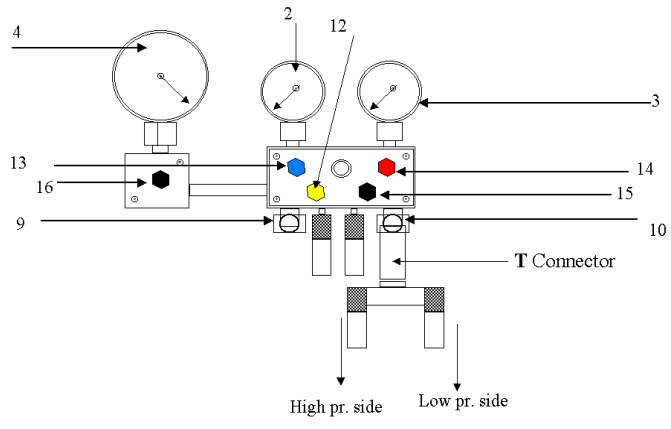

Gambar 3. Gauge Manifold empat laluan

Alat yang digunakan 1 unit mesin 3R (Recovery, Recycle dan Recharging), Tiga buah tabung refrigerant, Timbangan digital, Manifold, Pressure gauge,

\section{Prosedur Pengujian}

a. Siapkan mesin recovery, recycle dan recharging

b. Siapkan alat bantu yaitu pipa ekspansi, manifold gauge dan tabung refrigeran yang kosong.

c. Lakukan instalasi alat bantu ke mesin 3R dan unit mesin pendingin, pastikan sambungan pada pipa ekspansi sudah kuat.

d. Lakukan proses vakum tabung penampung refrigeran dengan menggunakan mesin $3 R$ (dilakukan setiap kali proses recovery, recycle \& recharging). e. Pasang alat ukur termometer digital pada kondisi I, II dan III.

f. Lakukan pengambilan data tekanan dan temperatur pada empat sisi proses yang dilakukan pada mesin.

g. Catat jumlah massa refrigeran hasil pemurnian hasil proses recovery, recycle dan recharging yang terlihat pada timbangan digital.

h. Lakukan prosedur pengujian ini pada setiap variasi pengujian yang dilakukan.

Pertama sampel freon diambil yaitu dengan cara mimindahkannya dari sistem (lemari es atau AC) ke tabung penampungan dengan proses vacum. Kemudian setelah itu freon tersebut di daur ulang dengan proses Recycle yaitu untuk memisahkan refrigeran dari pelumas, gas atau air. Setelah Freon terpisahkan dari kotoran ; pelumas, air atau gas, berarti Freon sudah steril maka Freon sudah bisa digunakan lagi, lalu froen dimasukan ke mesin Rechager untuk diisikan ke mesin pendingin kembali.

Beberapa data awal yang didapat dari pengukuran pada sampel Freon yaitu

Tabel 1. Pengukuran Freon R 22.

\begin{tabular}{|c|c|c|c|c|c|c|c|}
\hline Tekanan & Tekanan & \multicolumn{3}{|c|}{ Massa refrigeran (garam) } & \multicolumn{3}{|c|}{ Tekanan refrigeran sampel } \\
\cline { 3 - 8 } $\begin{array}{c}\text { Tabung } \\
(\text { Bar) }\end{array}$ & $\begin{array}{c}\text { Tabung } \\
(\mathrm{psig})\end{array}$ & $100 \mathrm{ml}$ & $200 \mathrm{ml}$ & $500 \mathrm{ml}$ & $32{ }^{\circ} \mathrm{C}$ & $40{ }^{\circ} \mathrm{C}$ & $60^{\circ} \mathrm{C}$ \\
\hline 6,83 & 100,4 & 128,5 & 257,0 & 642,5 & 6,83 & 8,58 & 14,22 \\
\hline
\end{tabular}

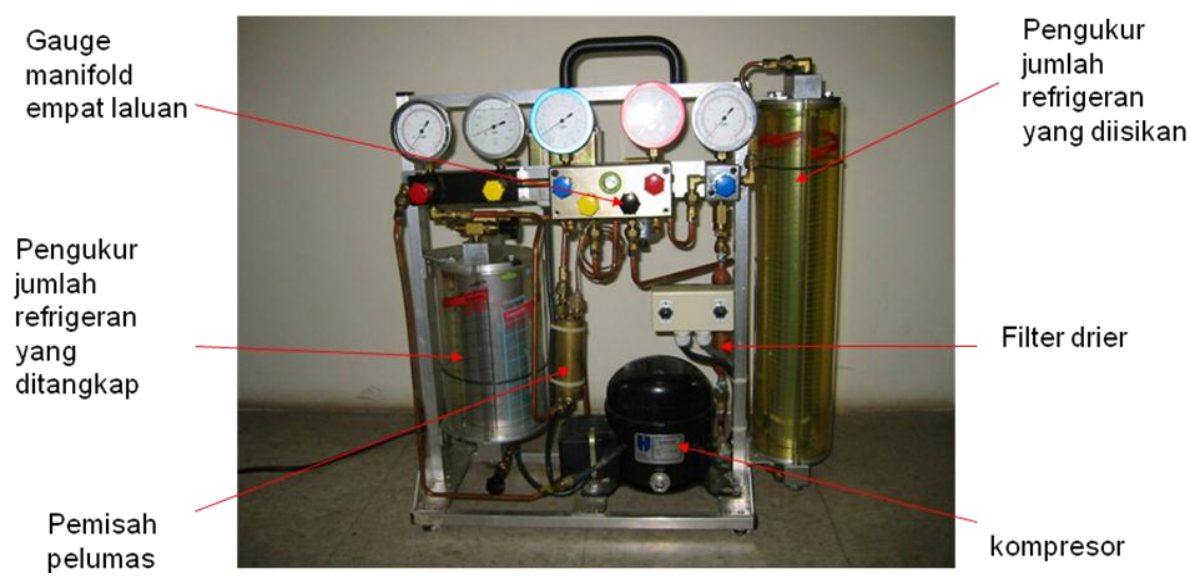

Gambar 4. Mesin Recovery, Recycle Dan Recharging 


\section{Kemas. Ridhuan}

\section{HASIL DAN PEMBAHSAN}

Data yang didapat dari hasil pengujian yang dilakukan terhadap sampel pada mesin daur ulang (Mesin Recovery) yaitu :

Tabel 2.Kondisi Sampel R-12 sebelum di daur ulang

\begin{tabular}{|c|c|c|c|}
\hline No. & $\begin{array}{c}\text { M a s s a (Wro) } \\
(\text { gram) }\end{array}$ & $\begin{array}{c}\text { Tekanan (Pro) } \\
(\mathbf{p s i})\end{array}$ & $\begin{array}{c}\text { Temperatur (Tro) } \\
\left({ }^{\circ} \mathbf{C}\right)\end{array}$ \\
\hline 01. & 30,11 & 15 & -12 \\
\hline 02. & 24,53 & 12 & -16 \\
\hline 03. & 20,60 & 17 & -9 \\
\hline 04. & 21,72 & 19 & -8 \\
\hline 05. & 26,41 & 13 & -15 \\
\hline
\end{tabular}

Tabel 3. Kondisi sampel R-12 setelah di daur ulang

\begin{tabular}{|c|c|c|c|c|c|}
\hline \multirow{2}{*}{ No. } & \multicolumn{3}{|c|}{ Refrigeran } & \multicolumn{2}{c|}{ Minyak Pelumas + Air } \\
\cline { 2 - 6 } & $\begin{array}{c}\text { Massa(Wri) } \\
(\mathbf{g r a m})\end{array}$ & $\begin{array}{c}\text { Tekanan(Pri) } \\
(\mathbf{p s i})\end{array}$ & $\begin{array}{c}\text { Temperatur(Tri) } \\
\left({ }^{\circ} \mathbf{C}\right)\end{array}$ & $\begin{array}{c}\text { Massa(Wpi) } \\
(\mathbf{g r a m})\end{array}$ & $\begin{array}{c}\text { Temperatur } \\
(\mathbf{T p i})\left({ }^{\circ} \mathbf{C}\right)\end{array}$ \\
\hline 01. & 25,93 & 13 & -15 & 3,48 & 16 \\
\hline 02. & 21,78 & 11 & -18 & 1,95 & 19 \\
\hline 03. & 16,99 & 15 & -12 & 2,71 & 14 \\
\hline 04. & 18,04 & 18 & -9 & 2,88 & 17 \\
\hline 05. & 22,11 & 12 & -17 & 3,50 & 11 \\
\hline
\end{tabular}

Selanjutnya data hasil pengujian di atas diolah kembali untuk mengetahui berapa persentase refrigeran dan pelumas serta kehilangan yang didapat. Pengolahan data di atas dapat diketahui dengan rumus :

1) Persentase hasil refrigeran

$$
\begin{aligned}
\operatorname{Re} & =\frac{\text { Wri }}{\text { Wro }} \times 100 \% \\
& =\frac{25,93}{30,11} \times 100 \% \\
& =86,12 \%
\end{aligned}
$$

2) Persentase hasil pelumas

$$
\begin{aligned}
\operatorname{Re} & =\frac{\text { Wri }}{\text { Wro }} \times 100 \% \\
& =\frac{3,48}{30,11} \times 100 \% \\
& =11,56 \%
\end{aligned}
$$

3) Jumlah massa kehilangan

$$
\begin{aligned}
\text { Wki } & =\text { Wro }- \text { Wri }- \text { Wpi } \\
& =30,11-25,93-3,48
\end{aligned}
$$

$$
=0,7 \text { gram }
$$

4) Persentase massa kehilangan

$$
\begin{aligned}
\text { Ke } & =\frac{\text { Wki }}{\text { Wro }} \times 100 \% \\
& =\frac{07}{30,11} \times 100 \% \\
& =2,32 \%
\end{aligned}
$$

Diketahui bahwa untuk masingmasing jenis refrigeran mempenyai massa yang berbeda, ini juga diukur berdasarkan temperatur dan tekanan refrigeran yang sama. Untuk refrigeran yang mengandung cloro flour massanya akan semakin besar. Dan untuk refrigeran yang hidro carbon cendrung massanya lebih kecil dibanding cloro flour. Semakin besar temperatur refrigeran maka tekanan refrigeran tersebut juga naik. Dan sebaliknya jika temperaturnya turun maka tekanannyapun akan turun. 
Tabel 4. Hasil dan persentase

\begin{tabular}{|c|c|c|c|c|c|c|}
\hline \multirow[b]{2}{*}{ No. } & \multicolumn{2}{|c|}{ Refrigeran } & \multicolumn{2}{|c|}{ Minyak Pelumas + Air } & \multicolumn{2}{|c|}{ Kehilangan } \\
\hline & $\begin{array}{c}\text { Massa(Wri) } \\
\text { (gr) }\end{array}$ & $\operatorname{Re}(\%)$ & $\begin{array}{c}\text { Massa(Wpi) } \\
\text { (gr) }\end{array}$ & $\operatorname{Pe}(\%)$ & $\begin{array}{c}\text { Massa(Wki) } \\
\text { (gr) }\end{array}$ & $\operatorname{Ke}(\%)$ \\
\hline 01. & 25,93 & 86,12 & 3,48 & 11,56 & 0,7 & 2,32 \\
\hline 02. & 21,78 & 88,79 & 1,95 & 7,95 & 0,8 & 3,26 \\
\hline 03. & 16,99 & 82,46 & 2,71 & 13,16 & 0.9 & 4,37 \\
\hline 04. & 18,04 & 83,06 & 2,88 & 13,26 & 0,8 & 3,68 \\
\hline 05. & 22,11 & 83,72 & 3,50 & 13,25 & 0,8 & 3,03 \\
\hline $\begin{array}{l}\text { Rata- } \\
\text { rata }\end{array}$ & 20,97 & 84,83 & 2,90 & 11,84 & 0,8 & 3,33 \\
\hline
\end{tabular}

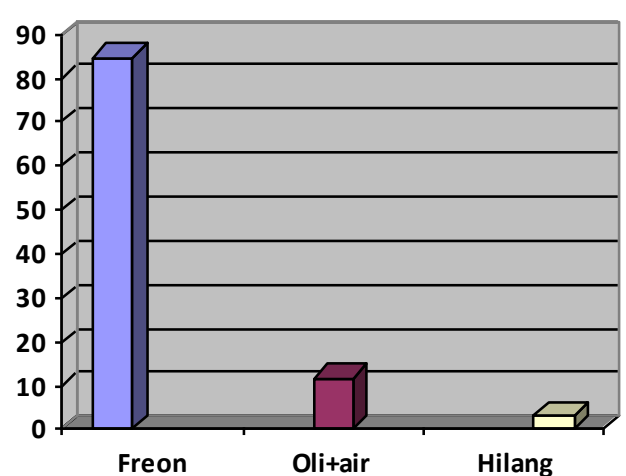

Gambar 5. Grafik hasil pemisahan

Jika tekanan refriregan naik maka temperaturnyapun juga naik, begitu pula sebaliknya. Namun ukuran ini tidak diikuti oleh ukuran massa refrigerannya. Dimana kenaikan tekanan dan temperaturnya, tidak dibarengi kenaikan oleh massa sampelnya. Ini menunjukkan bahwa massa refrigeran tidak berhubungan dengan tekanan dan temperaturnya.

jumlah refrigeran yang setelah didaur ulang (setelah dipisahkan dengan pelumas) masih cukup besar yang didapat yaitu ratarata 20,97 gram. Hubungan antara tekanan dan temperatur adalah berbanding lurus dan saling berkaitan. Jumlah massa pelumas yang diperoleh rata-rata 2,90 gram. Banyaknya massa pelumas yang diperoleh tidak dapat dihubungkan langsung dengan banyaknya massa refrigeran yang didaur ulang, tetapi dipengaruhui oleh beberapa hal seperti jenis dan merek pelumas, jenis dan merek kompresor, jenis refrigeran yang digunakan, usia sistem (alat pendingin). Jenis/merk minyak pelumas ini sangat mempengaruhi viskositas atau tingkat kekentalannya. Semakin kental minyak pelumasnya maka kemungkinan akan semakin sedikit ia akan mencemari refrigeran,

\section{KESIMPULAN}

1. Berdasarkan hasil dan pembahasan di atas, maka dapat diambil beberapa kesimpulan dari penelitian ini yaitu :

2. Adanya hubungan yang langsung antara tekanan dan temperatur refrigerant yang digunakan. Semakin besar tekanan maka temperaturnyapun akan semakin besar dan sebaliknya semakin kecil tekanan refrigeran maka temperaturnyapun akan kecil.

3. Setelah pengujian terlihat bahwa adanya pengurangan massa refrigeran setelah dipisahkan dengan pelumas. Kemudian penurunan tekanan yang diikuti oleh penurunan temperatur dari refrigeran, hal ini menunjukan pengaruh pemisahan pelumas dari refrigeran bisa berdampak baik bagi kondisi refrigeran (lebih dingin) dan sementara temperatur pelumas manjadi meningkat jauh dari temperatur refrigeran. Hal ini memperlihatkan kondisi pelumas mau kembali pada keadaan semula. 
4. Jumlah refrigeran yang diperoleh setelah daur ulang cukup besar rata-rata 20,97 gram atau sekitar $84,83 \%$, hal ini sangat baik untuk peningkatan efisiensi. Kemudian jumlah pelumas yang dipisahkan dari refrigeran rata-rata 2,90 gram sekitar $11,84 \%$. Serta kehilangan akibat menempel atau lengket dimasingmasing komponen terutama pada filter sekitar 0,8 gram atau 3,33 \%. Ini menunjukan bahwa proses daur ulang sangat efektif dan efisien seperti pada tabel4 dan gambar 5 .

\section{DAFTAR PUSTAKA}

1. Conserns Cool, 2000, Petunjuk Peralatan Rumah Tangga dan Komersil, Ecorfrig, Jakarta

2. F. Stoecker Wilbert, W. Jones Jerod, Supratman Hara, 1989, Refrigerasi dan Pengkondisian Udara,Penerbit Erlangga, Jakarta

3. GTP. Service, Equipmen, 2006, Recoplus 123, Italia

4. GTP. Service, 2006, ACS, Ike Coplus, Italia

5. Mulyanef, Suryadimal dan Rico Andika, 2007, Mesin 3r (Recovery, Recycle Dan Recharging) Untuk Mengurangi Efek Pencemaran Atmosfir Bumi Akibat Refrigeran Mesin Pendingin, Teknik Mesin Univ. Bung Hatta.

6. SNI, 2000, Refrigeran : Pemakaian Pada Instalasi Tetap, Badan Standarisasi Nasional Jakarta.

7. SNI, 2000, Refrigeran Kelompok A 3 Pemakaian pada Mesin tata Udara Kendaraan Bermotor

8. SNI, 2000, Refrigeran Kelompok A 3. Keamanan Pengisian, Penyimpanan dan transfortasi 